\title{
Discussions and decisions of the 2012-2014 International Committee on Taxonomy of Viruses (ICTV) Filoviridae Study Group, January 2012-June 2013
}

\author{
Alexander A. Bukreyev $\cdot$ Kartik Chandran $\cdot$ Olga Dolnik $\cdot$ John M. Dye $\cdot$ Hideki Ebihara \\ Eric M. Leroy • Elke Mühlberger • Sergey V. Netesov • Jean L. Patterson • \\ Janusz T. Paweska • Erica Ollmann Saphire - Sophie J. Smither • Ayato Takada • \\ Jonathan S. Towner • Viktor E. Volchkov • Travis K. Warren • Jens H. Kuhn
}

Received: 10 July 2013/Accepted: 2 August 2013/Published online: 13 October 2013

(C) Springer-Verlag Wien (outside the USA) 2013

\begin{abstract}
The International Committee on Taxonomy of Viruses (ICTV) Filoviridae Study Group prepares proposals on the classification and nomenclature of filoviruses to reflect current knowledge or to correct disagreements with the International Code of Virus Classification and Nomenclature (ICVCN). In recent years, filovirus taxonomy has been corrected and updated, but parts of it remain controversial, and several topics remain to be debated. This article summarizes the decisions and discussion of the currently acting ICTV Filoviridae Study Group since its inauguration in January 2012.
\end{abstract}

A. A. Bukreyev, K. Chandran, O. Dolnik, J. M. Dye, H. Ebihara, E. M. Leroy, E. Mühlberger, S. V. Netesov, J. L. Patterson, J. T. Paweska, E. O. Saphire, S. J. Smither, A. Takada, J. S. Towner, V. E. Volchkov, T. K. Warren, and J. H. Kuhn are the members of the 2012-2014 International Committee on Taxonomy of Viruses (ICTV) Filoviridae Study Group.

The content of this publication does not necessarily reflect the views or policies of the US Department of the Army, the US Department of Defense or the US Department of Health and Human Services or of the institutions and companies affiliated with the authors. JHK performed this work as an employee of Tunnell Consulting, Inc., a subcontractor to Battelle Memorial Institute under its prime contract with NIAID, under Contract No. HHSN272200700016I.

\section{A. A. Bukreyev}

Department of Pathology and Galveston National Laboratory, University of Texas Medical Branch, Galveston, TX, USA

\section{K. Chandran}

Department of Microbiology and Immunology, Albert Einstein College of Medicine, Bronx, NY, USA

O. Dolnik Institut für Virologie, Philipps-Universität Marburg, Marburg, Germany

\section{Introduction}

The International Committee on Taxonomy of Viruses (ICTV) is a committee of the Virology Division of the International Union of Microbiological Societies (IUMS) responsible for virus taxonomy, i.e., the organization of viruses into hierarchical taxa and their nomenclature [5]. The decisions of the ICTV are informed by advice from specialist groups, the ICTV Study Groups, which generally are composed of experts on members of particular virus families [5]. Updates on virus taxonomy are published at regular intervals in the form of ICTV Reports and, between reports, in the form of Virology Division News (VDN) articles in Archives of Virology [5]. Taxonomic proposals can be made by individuals and are then evaluated by the responsible Study Group. Alternatively, the Study Group prepares proposals or works hand-in-hand with other experts to propose new taxa or nomenclature changes. Submitted official proposals are then evaluated by the ICTV Executive Committee for rationale and compliance with the International Code of Virus Classification and Nomenclature (ICVCN) [6] and, if approved, posted online for public comment (www.ictvonline.org) and forwarded to the ICTV members for ratification [5]. Here, we summarize the decisions and discussions of the currently acting ICTV Filoviridae Study Group since its inauguration

\footnotetext{
J. M. Dye - T. K. Warren

United States Army Medical Research Institute of Infectious

Diseases, Fort Detrick, Frederick, MD, USA

H. Ebihara

Rocky Mountain Laboratories Integrated Research Facility, National Institute of Allergy and Infectious Diseases, National Institutes of Health, Hamilton, MT, USA
} 
in January 2012 to increase transparency of these processes for the filovirology community.

\section{Establishment of the 2012-2014 ICTV Filoviridae Study Group}

According to the Statutes of the ICTV, ICTV Study Groups are to be dissolved at regular intervals by the President of the ICTV at the time of an ICTV Plenary Session, which usually coincides with the triennial International Congress of Virology (ICV) (Statutes Article 5.1 [5]). Consequently, Eric B. Carstens, who was confirmed as ICTV President by the ICTV membership for his second and final three-year term (Statutes Article 4.3A [5]) during the XVth ICV in Sapporo, Japan, in September 2011, dissolved the thenacting 2010-2011 ICTV Filoviridae Study Group on September 14, 2011. The ICTV Statutes mandate that the elected Chairs of the ICTV Executive Committee Virus Subcommittees, which are elected for a maximum of two three-year terms by the ICTV Executive Committee (Statute Article 4.3B [5]), appoint new Chairs for all Study Groups (Statute Article 4.5 [5]) subsequent to an ICTV Plenary Session. The Chair's task is to assemble a new Study Group for the time period until the next ICTV Plenary Session (Statute Article 4.5 [5]). On October 20, 2011, Andrew J. Davison, confirmed in Sapporo for his second and final three-year term as Chair of the ICTV Vertebrate Virus Subcommittee, appointed Jens H. Kuhn as the Chair of the new ICTV Filoviridae Study Group. The Study

\section{E. M. Leroy \\ Centre International de Recherches Médicales de Franceville, Institut de Recherche pour le Développement (IRD), Franceville, Gabon \\ E. Mühlberger \\ Department of Microbiology and National Emerging Infectious Diseases Laboratory, Boston University School of Medicine, Boston, MA, USA \\ S. V. Netesov \\ Novosibirsk State University, Novosibirsk Oblast, Novosibirsk, Russia}

\section{J. L. Patterson}

Department of Virology and Immunology, Texas Biomedical

Research Institute, San Antonio, TX, USA

\section{J. T. Paweska}

Center for Emerging and Zoonotic Diseases, National Institute for Communicable Diseases of the National Health Laboratory Service, Sandringham, Johannesburg, Gauteng, South Africa

\section{E. O. Saphire}

Department of Immunology and Microbial Science and The Skaggs Institute for Chemical Biology, The Scripps Research Institute, La Jolla, CA, USA
Group Chair then began inviting members of the filovirus research community to join the group. Emphasis was placed on choosing members that

- have an interest in filovirus taxonomy and/or a general knowledge of virus taxonomy;

- have contributed to filovirology;

- have expertise in subspecialties pertaining to virus classification (molecular biology, molecular virology, structural biology, serology or ecology);

- represent the majority of biosafety level 4 (BSL-4) laboratories currently performing filovirus research with replicating isolates;

- come from different countries, speaking different languages;

- represent both genders; and

- represent a broad age range.

Furthermore, decisions were made to establish a rather large study group (17 members) to include many voices in the decision process and to keep the total number of group members uneven. On January 26, 2012, the Study Group Chair forwarded the final composition of the new Study Group (Table 1) to Andrew J. Davison, and the Study Group became active. The following rules were established by the Study Group Chair:

- Study Group decisions are made by electronic (email) voting.

- Study Group members vote according to their own opinions and not on behalf of others.

\section{S. J. Smither}

Biomedical Sciences Department, DSTL, Porton Down,

Salisbury, Wiltshire, UK

A. Takada

Division of Global Epidemiology, Hokkaido University

Research Center for Zoonosis Control, Sapporo, Japan

\section{J. S. Towner}

Viral Special Pathogens Branch, Division of High-Consequence Pathogens Pathology, National Center for Emerging and

Zoonotic Infectious Diseases, Centers for Disease Control and Prevention, Atlanta, GA, USA

\section{E. Volchkov}

Laboratoire des Filovirus, Inserm U758, Université de Lyon, UCB-Lyon-1, Ecole-Normale-Supérieure de Lyon, Lyon, France

\section{J. H. Kuhn ( $\square)$}

Integrated Research Facility at Fort Detrick (IRF-Frederick), Division of Clinical Research (DCR), National Institute of Allergy and Infectious Diseases (NIAID), National Institutes of Health (NIH), B-8200 Research Plaza, Fort Detrick, Frederick, MD 21702, USA

e-mail: kuhnjens@mail.nih.gov 
Table 1 Membership of the 2012-2014 ICTV Filoviridae Study Group

\begin{tabular}{|c|c|}
\hline Name (degree) & Affiliation \\
\hline $\begin{array}{l}\text { Bukreyev, Alexander A. } \\
\quad(\mathrm{PhD})\end{array}$ & $\begin{array}{l}\text { Department of Pathology and Galveston National Laboratory (GNL), University of Texas Medical Branch } \\
\text { (UTMB), Galveston, Texas, USA }\end{array}$ \\
\hline Chandran, Kartik (PhD) & Department of Microbiology and Immunology, Albert Einstein College of Medicine, Bronx, New York, USA \\
\hline Dolnik, Olga $(\mathrm{PhD})$ & Institut für Virologie, Philipps-Universität Marburg, Marburg, Germany \\
\hline Dye, John M., Jr. (PhD) & $\begin{array}{l}\text { United States Army Medical Research Institute of Infectious Diseases (USAMRIID), Fort Detrick, Frederick, } \\
\text { Maryland, USA }\end{array}$ \\
\hline Ebihara, Hideki (PhD) & $\begin{array}{l}\text { Rocky Mountain Laboratories Integrated Research Facility (RML-IRF), National Institute of Allergy and } \\
\text { Infectious Diseases, National Institutes of Health, Hamilton, MT, USA }\end{array}$ \\
\hline $\begin{array}{l}\text { Kuhn, Jens H. (MD, PhD, } \\
\text { PhD, MS) }\end{array}$ & $\begin{array}{l}\text { Integrated Research Facility at Fort Detrick (IRF-Frederick), National Institute of Allergy and Infectious Diseases } \\
\text { (NIAID), National Institutes of Health (NIH), Fort Detrick, Frederick, Maryland, USA }\end{array}$ \\
\hline Leroy, Eric M. (DVM, PhD) & $\begin{array}{l}\text { Centre International de Recherches Médicales de Franceville (CIRMF), Institut de Recherche pour le } \\
\text { Développement (IRD), Franceville, Gabon }\end{array}$ \\
\hline Mühlberger, Elke (PhD) & $\begin{array}{l}\text { Department of Microbiology and National Emerging Infectious Diseases Laboratory (NEIDL), Boston University } \\
\text { School of Medicine, Boston, Massachusetts, USA }\end{array}$ \\
\hline $\begin{array}{l}\text { Netesov, Sergey V. (PhD, } \\
\text { DSci) }\end{array}$ & Novosibirsk State University, Novosibirsk, Novosibirsk Oblast, Russia \\
\hline Patterson, Jean L. (PhD) & $\begin{array}{l}\text { Department of Virology and Immunology, Texas Biomedical Research Institute (TBRI), San Antonio, Texas, } \\
\text { USA }\end{array}$ \\
\hline $\begin{array}{l}\text { Paweska, Janusz T. (DVSc, } \\
\text { Dr hab) }\end{array}$ & $\begin{array}{l}\text { Center for Emerging and Zoonotic Diseases, National Institute for Communicable Diseases of the National Health } \\
\text { Laboratory Service (NICD), Sandringham-Johannesburg, Gauteng, South Africa }\end{array}$ \\
\hline Saphire, Erica O. (PhD) & $\begin{array}{l}\text { Department of Immunology and Microbial Science and The Skaggs Institute for Chemical Biology, The Scripps } \\
\text { Research Institute, La Jolla, California, USA }\end{array}$ \\
\hline Smither, Sophie J. (PhD) & Biomedical Sciences Department, Dstl, Porton Down, Salisbury, Wiltshire, UK \\
\hline Takada, Ayato (DVM, PhD) & Division of Global Epidemiology, Hokkaido University Research Center for Zoonosis Control, Sapporo, Japan \\
\hline Towner, Jonathan S. (PhD) & $\begin{array}{l}\text { Viral Special Pathogens Branch (VSPB), Division of High-Consequence Pathogens Pathology, National Center } \\
\text { for Emerging and Zoonotic Infectious Diseases (NCEZID), Centers for Disease Control and Prevention (CDC), } \\
\text { Atlanta, Georgia, USA }\end{array}$ \\
\hline Volchkov, Viktor E. (PhD) & $\begin{array}{l}\text { Laboratoire des Filovirus, Inserm U758, Université de Lyon, UCB-Lyon-1, Ecole-Normale-Supérieure de Lyon, } \\
\text { Lyon, France }\end{array}$ \\
\hline Warren, Travis K. (PhD) & $\begin{array}{l}\text { United States Army Medical Research Institute of Infectious Diseases (USAMRIID), Fort Detrick, Frederick, } \\
\text { Maryland, USA }\end{array}$ \\
\hline
\end{tabular}

- A simple majority (9 out of 17 votes) decides a vote.

- The Study Group Chair will not break a split vote (8:8) but will postpone a decision until a clear vote is reached after extended debate.

- Any decided vote counts as the consensus of the group.

- All Study Group members abide by a decision in their own written or oral proceedings as well as in peer review (in the function of reviewer or editor) to achieve general acceptance of changes as quickly as possible.

- An absent vote by a given deadline counts as a vote in support of the majority vote at that time.

\section{Review of decisions made by the 2010-2011 ICTV Filoviridae Study Group}

The previous, 2010-2011, ICTV Filoviridae Study Group proposed broad changes to filovirus taxonomy to address problems seen with the then-current 2005-2011 taxonomy (Table 2) [7]. The following problems were addressed:
- in 2005, the then still commonly used virus names "Ebola virus" and "Marburg virus" were unfortunately taken to create very similar looking genus names ("Ebolavirus", "Marburgvirus") [3]. This move created continuing confusion of individual viruses and entire groups of viruses (Ebola virus vs. ebolaviruses; Marburg virus vs. marburgviruses).

- the filovirus names in use at the time did not match the commonly used virus-naming format ("xxx virus", such as "Lassa virus", "Rift Valley fever virus", "Nipah virus"). Instead, the virus names were non-Latinized binomials (e.g., "Zaire ebolavirus", "Lake Victoria marburgvirus"). Aside from being unusual, binomial virus names are problematic, as they contain genus name information. Virus name changes would be required if, for one reason or another, future reclassification required the abolishment of the genus or the reclassification of genus members into a different genus. However, virus names should remain as constant over time as possible and should therefore be unaffected by taxon name changes. 
Table 2 Changes in the 2005-2011 filovirus taxonomy

\begin{tabular}{lc}
\hline Previous (2005-2011) taxonomy (Eighth ICTV Report) [3] & $\begin{array}{c}\text { Current (2011-present) filovirus taxonomy } \\
\text { (Ninth ICTV Report and updates) [1, 7, 8] }\end{array}$ \\
\hline Order Mononegavirales & Order Mononegavirales \\
Family Filoviridae & Family Filoviridae \\
Genus Marburgvirus & Genus Marburgvirus \\
Species Lake Victoria marburgvirus & Species Marburg marburgvirus \\
Virus: Lake Victoria marburgvirus (MARV) & Virus 1: Marburg virus (MARV) \\
& Virus 2: Ravn virus (RAVV) \\
Genus Ebolavirus & Genus Ebolavirus \\
Species Cote d'Ivoire ebolavirus [sic] & Species Taï Forest ebolavirus \\
Virus: Cote d'Ivoire ebolavirus [sic] (CIEBOV) & Virus: Taï Forest virus (TAFV) \\
Species Reston ebolavirus & Species Reston ebolavirus \\
Virus: Reston ebolavirus (REBOV) & Virus: Reston virus (RESTV) \\
Species Sudan ebolavirus & Species Sudan ebolavirus \\
Virus: Sudan ebolavirus (SEBOV) & Virus: Sudan virus (SUDV) \\
Species Zaire ebolavirus & Species Zaire ebolavirus \\
Virus: Zaire ebolavirus (ZEBOV) & Virus: Ebola virus (EBOV) \\
& Species Bundibugyo ebolavirus \\
& Virus: Bundibugyo virus (BDBV) \\
\hline
\end{tabular}

- the filovirus names in use at the time were identical in spelling to the names of the species they were assigned to and only differed by the absence or presence of italics (e.g., Zaire ebolavirus was the only member of the species Zaire ebolavirus; Lake Victoria marburgvirus was the only member of the species Lake Victoria marburgvirus). This problem is found across the entire ICTV nomenclature and violates the ICVCN because viruses and species need to be clearly differentiated (Rule 3.14: "New names shall not duplicate approved names. New names shall be chosen such that they are not closely similar to names that are in use currently or have been in use in the recent past"; Rule 3.23: "A species name shall consist of as few words as practicable but be distinct from names of other taxa"; and Rule 3.24: "A species name must provide an appropriately unambiguous identification of the species" [6]). Taxonomy experts have proposed and are in the process of addressing the problem of identical virus and species names by introducing non-Latinized binomial names for species (e.g., the species name Measles morbillivirus could be used to differentiate it from its member, measles virus) [17]. Unfortunately, in the case of filoviruses, this approach was not helpful because both the species and virus names had already been established in non-Latinized binomial form. Confusion ensued. In particular, numerous filovirus publications exist, and are still being published, in which (italicized) species names were used when (non-italicized) virus names should have been used.
- the filovirus names in use at the time were neither accepted by the filovirus community nor by the press. The virus names "Marburg virus" and "Ebola virus" continued to dominate publication titles and press reports despite the fact that these names officially did not exist anymore ("Lake Victoria marburgvirus" and "Zaire ebolavirus" should have been used instead).

- it is practice in virology that the discoverer of a virus assigns it a name and that this name is honored by the community. "Marburg virus" and "Ebola virus" were the names chosen by their discoverers (Rudolf Siegert [15] and Karl M. Johnson [4], respectively), but these names did not exist in the 2005-2011 taxonomy anymore.

- the species name "Taï Forest ebolavirus" was officially established during a Plenary Session in 2002 for an ebolavirus discovered in Côte d'Ivoire in 1994. However, due to an oversight, this change was not incorporated into the Eighth ICTV Report and instead the unaccepted and (misspelled) "Cote d'Ivoire ebolavirus" entered the literature [3].

- several virus acronyms ("CIEBOV", "SEBOV", "ZEBOV") were difficult to differentiate during oral proceedings.

- the taxonomy did not differentiate between the two very distinct lineages of marburgviruses ("Ravn" marburgviruses versus other marburgviruses)

- a novel ebolavirus ("Bundibugyo") was discovered in Uganda [16] and needed to be classified.

- the Study Group was informed that the genomic sequence of a novel filovirus ("Lloviu”) was determined. 
Unpublished data were shared with the group, and it became clear that this new agent would have to be classified eventually.

The 2010-2011 Study Group therefore officially proposed, among others, the following solutions [7]:

- re-instate the names "Ebola virus" and "Marburg virus" to honor the discoverers of these viruses and to be in line with manuscript titles and press articles. Consequently, the now unsuitable virus acronym "ZEBOV" was replaced with the abbreviation used for this virus since its discovery ("EBOV"), whereas the acronym MARV, which was used in the past for both "Marburg virus" and for "Lake Victoria marburgvirus" could be retained.

- re-introduce the ebolavirus species name "Taï Forest ebolavirus" to address the oversight in the ICTV's Eighth Report.

- change the names of the viruses assigned to the species Sudan ebolavirus (Sudan ebolavirus), Reston ebolavirus (Reston ebolavirus), and Taï Forest ebolavirus (Cote d'Ivoire ebolavirus) to Sudan virus, Reston virus, and Taï Forest virus, respectively, so they adhere to common virus-naming formats and can be clearly differentiated from the respective species names, while at the same time "sounding familiar" to the filovirus research community. Consequently, new virus abbreviations needed to be introduced.

- elevate the "Ravn" lineage of marburgviruses to virus level ("Ravn virus"), but assign it to the same species as the "Marburg" lineage of marburgviruses ("Marburg virus").

- create a novel ebolavirus species for "Bundibugyo", but defer making a proposal for creating a novel species for "Lloviu" until the description of the near-complete genome of the new virus is published.

The ICTV Executive Committee accepted the taxonrelevant parts of these proposals after they had been online for one year without any opposition or comment from the virology community. The IUMS Virology Division ratified all proposals at the end of 2011 [1]. An outline of this currently official ICTV filovirus taxonomy is contrasted with the previous taxonomy in Table 2 .

\section{Discussions and decisions by the 2012-2014 ICTV Filoviridae Study Group in 2012}

Discussions on filovirus taxonomy were initiated among all Study Group members via email immediately after inauguration of the new group in January 26, 2012, and continued until the ICTV deadline for submission of new proposals for that year, on July 2, 2012.

\section{Filovirus classification}

The group members, in a 17:0 vote, confirmed that the current 2010-2011 classification of seven filoviruses into one family, two genera, and six species (Table 2, right column) was adequate and ought to be maintained. Based on the publication of a research paper describing "Lloviu" in detail [13], the group, in a 17:0 vote, officially submitted a proposal to ICTV to establish a third filoviral genus, "Cuevavirus", including a single species, "Lloviu cuevavirus" for a new virus, Lloviu virus (LLOV). On August 2, 2012, the group was informed that there was unanimous support for this proposal by the ICTV Executive Committee ("provisionally accepted"), but that it would have to be posted for public comment before a final decision could be made. However, on November 19, 2012, the group was informed that despite the absence of public comments, the decision would be postponed to the next ICTV Executive Committee meeting in July 2013 due to perceived shortcomings of the proposal that would have to be addressed by the Study Group.

\section{Filovirus nomenclature}

Six of seventeen group members pointed out that the current filovirus nomenclature is not $100 \%$ consistent. While most of the current species names now allowed to deduce the genus and virus name (species Sudan ebolavirus $\rightarrow$ genus Ebolavirus $\rightarrow$ Sudan virus; species Taï Forest ebolavirus $\rightarrow$ genus Ebolavirus $\rightarrow$ Taï Forest virus), this is not true for the species Zaire ebolavirus ( $\rightarrow$ genus Ebolavirus, but Ebola virus rather than "Zaire virus").

Furthermore, it became evident that the current nomenclature causes confusion among some community members because the words "Ebola virus" and "Ebolavirus/ebolavirus" and "Marburg virus" and "Marburgvirus/marburgvirus/ Marburg marburgvirus" are too similar in writing and pronunciation. Consequently, researchers are required to understand the difference and distinguish in writing between an ebolavirus (any member of the genus Ebolavirus) and Ebola virus (the member of the species Zaire ebolavirus in the genus Ebolavirus); or between a marburgvirus (any member of the genus Marburgvirus) and Marburg virus (a specific member of the species Marburg marburgvirus). Also, filovirus community members still erroneously tend to abbreviate members of taxa higher than species, and therefore often use the abbreviation "EBOV" for all ebolaviruses, rather than only Ebola virus. Several suggestions for solutions were brought forward to solve these issues:

- Ebola virus (EBOV) could be renamed "Zaire virus" and a new abbreviation could be assigned to this virus (Table 3). 
Table 3 Discussed possibilities to solve existing filovirus nomenclature problems (possible changes underlined)

\begin{tabular}{|c|c|c|c|}
\hline $\begin{array}{l}\text { Current (2011-present) filovirus } \\
\text { taxonomy (Ninth ICTV Report } \\
\text { and updates) }[1,7,8]\end{array}$ & $\begin{array}{l}\text { Possibility 1: change of virus } \\
\text { name, necessitating virus } \\
\text { abbreviation change }\end{array}$ & $\begin{array}{l}\text { Possibility 2: species name } \\
\text { change }\end{array}$ & $\begin{array}{l}\text { Possibility 3: genus name } \\
\text { changes }\end{array}$ \\
\hline Order Mononegavirales & Order Mononegavirales & Order Mononegavirales & Order Mononegavirales \\
\hline Family Filoviridae & Family Filoviridae & Family Filoviridae & Family Filoviridae \\
\hline Genus Marburgvirus & Genus Marburgvirus & Genus Marburgvirus & Genus Marvirus ${ }^{\mathrm{b}}$ \\
\hline Species Marburg marburgvirus & Species Marburg marburgvirus & Species Marburg marburgvirus & Species Marburg marvirus \\
\hline $\begin{array}{l}\text { Virus 1: Marburg virus } \\
\text { (MARV) }\end{array}$ & $\begin{array}{l}\text { Virus 1: Marburg virus } \\
\text { (MARV) }\end{array}$ & $\begin{array}{l}\text { Virus 1: Marburg virus } \\
\text { (MARV) }\end{array}$ & $\begin{array}{l}\text { Virus 1: Marburg virus } \\
\text { (MARV) }\end{array}$ \\
\hline Virus 2: Ravn virus (RAVV) & Virus 2: Ravn virus (RAVV) & Virus 2: Ravn virus (RAVV) & Virus 2: Ravn virus (RAVV) \\
\hline Genus Ebolavirus & Genus Ebolavirus & Genus Ebolavirus & 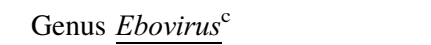 \\
\hline Species Taï Forest ebolavirus & Species Taï Forest ebolavirus & Species Taï Forest ebolavirus & Species Tä̈ Forest ebovirus \\
\hline Virus: Taï Forest virus (TAFV) & Virus: Taï Forest virus (TAFV) & Virus: Taï Forest virus (TAFV) & Virus: Taï Forest virus (TAFV) \\
\hline Species Reston ebolavirus & Species Reston ebolavirus & Species Reston ebolavirus & Species Reston ebovirus \\
\hline Virus: Reston virus (RESTV) & Virus: Reston virus (RESTV) & Virus: Reston virus (RESTV) & Virus: Reston virus (RESTV) \\
\hline Species Sudan ebolavirus & Species Sudan ebolavirus & Species Sudan ebolavirus & Species Sudan ebovirus \\
\hline Virus: Sudan virus (SUDV) & Virus: Sudan virus (SUDV) & Virus: Sudan virus (SUDV) & Virus: Sudan virus (SUDV) \\
\hline Species Zaire ebolavirus & Species Zaire ebolavirus & Species Ebola ebolavirus & Species Ebola ebovirus \\
\hline Virus: Ebola virus (EBOV) & Virus: $\underline{\text { Zaire }}$ virus $\left(\underline{\mathrm{ZAIV}}^{\mathrm{a}}\right)$ & Virus: Ebola virus (EBOV) & Virus: Ebola virus (EBOV) \\
\hline Species Bundibugyo ebolavirus & Species Bundibugyo ebolavirus & Species Bundibugyo ebolavirus & Species Bundibugyo ebovirus \\
\hline $\begin{array}{l}\text { Virus: Bundibugyo virus } \\
\text { (BDBV) }\end{array}$ & $\begin{array}{l}\text { Virus: Bundibugyo virus } \\
\text { (BDBV) }\end{array}$ & $\begin{array}{l}\text { Virus: Bundibugyo virus } \\
\text { (BDBV) }\end{array}$ & $\begin{array}{l}\text { Virus: Bundibugyo virus } \\
\text { (BDBV) }\end{array}$ \\
\hline
\end{tabular}

" Or any other abbreviation suitable for the words "Zaire virus"

b Or any other word stem not containing the word "Marburg"

c Or any other word stem not containing the word "Ebola"

- Advantages: the entire filovirus nomenclature would be consistent, as the species name Zaire ebolavirus would correctly predict the genus name (Ebolavirus) and the virus name (Zaire virus); the words "Ebolavirus/ebolavirus" could not be confused with the term "Ebola virus" anymore.

- Disadvantages: the term "Ebola virus" and the abbreviation "EBOV," used in virtually every publication on filoviruses since 1976 and in numerous press reports, would officially disappear. Additionally, abolishing this term is against the will of the discoverer of the virus. Finally, the problem of "Marburg virus" vs. "marburgvirus" would remain unresolved.

- Result of voting: originally 3 out of 17 votes in favor; but 2 votes reversed after conversing with the discoverer of Ebola virus (final tally 1 out of 17 votes in factor).

- Alternatively, the species name Zaire ebolavirus could be renamed Ebola ebolavirus (Table 3).

- Advantage: the entire filovirus nomenclature would be consistent, as the species name Ebola ebolavirus would correctly predict the genus name (Ebolavirus) and the virus name (Ebola virus).
- Disadvantage: although in line with numerous similar looking species names in zoology (Gorilla gorilla gorilla, Homo sapiens sapiens, Rattus rattus), a species name Ebola ebolavirus is not pleasing to the eye and causes confusion on the vernacular name level ("Ebola virus, assigned to the species Ebola ebolavirus, is more lethal than other ebolaviruses"...). The problem of "Marburg virus" vs. "marburgvirus" would remain unresolved.

- Result of voting: 2 out of 17 votes in favor.

- Alternatively, the genus names Ebolavirus and Marburgvirus could be changed to new names and the included species names adjusted (Table 3).

- Advantage: the entire filovirus nomenclature would become consistent, as "Ebola virus" would become the only filovirus name containing the word "Ebola" and "Marburg virus" would become the only filovirus name containing the word "Marburg".

- Disadvantage: all species names would have to be changed, and although the actual change would be minimal, it would most likely be perceived as radical.

- Result of voting: 2 out of 17 votes in favor. 
Other suggestions for nomenclature changes by Study Group members included

- reverting the species name Marburg marburgvirus to Lake Victoria marburgvirus (1 out of 17 votes in favor).

- changing the species name Taï Forest ebolavirus name to Côte d'Ivoire ebolavirus with Taï Forest virus (TAFV) as its member (originally 1 vote in favor but later withdrawn).

- changing the virus name Sudan virus (SUDV) to "Nzara virus" and giving the virus a new abbreviation (1 out of 17 votes in favor).

- returning to the old virus abbreviations REBOV, SEBOV, and ZEBOV (2 out of 17 votes in favor).

- changing the abbreviation "EBOV" for Ebola virus to something else ( 2 out of 17 votes in favor).

In a final tally, the Study Group members voted in favor of not changing the current nomenclature, but to continue the discussion on how to solve the "Ebola virus/ebolavirus, Marburg virus/marburgvirus" issue.

\section{Discussions and decisions by the 2012-2014 ICTV Filoviridae Study Group in 2013}

Discussions on filovirus taxonomy were re-initiated among all Study Group members via email on March 20, 2013, and continued until the ICTV deadline for submission of new proposals for this year, on June 24, 2013.

\section{Does filovirus classification need to be changed?}

Since closure of Study Group discussions in 2012, three scientific papers informing filovirus classification have been published.

The first study was conducted by Bao et al. [2], who analyzed 52 complete or near-complete filovirus genome sequences employing the National Center for Biotechnology Information (NCBI) PAirwise Sequence Comparison (PASC) tool using local alignment based on the Basic Local Alignment Search Tool (BLAST). This study confirmed the current classification of eight filoviruses in one family, three genera, and seven species (Table 2, right column). Importantly, the study confirmed the classification of Ravn virus separately from Marburg virus and the need to classify LLOV into a new species included in a new genus [2]. Filovirus taxa demarcation criteria were determined to be 64-77\% genome similarity for species and 41-50\% genome similarity for genera [2], which is roughly in agreement with the currently established $70 \%$ genome similarity cutoff for species and the $50 \%$ genome similarity cutoff for genera [7].
The second study was published by Lauber et al. [12], who evaluated filovirus classification using 56 complete or nearcomplete filovirus genome sequences employing Diversity Partitioning by Hierarchical Clustering (DEmARC) analysis. Once again, the current classification was confirmed, although Lauber et al. [12] identified a need for additional filovirus genomic sequence data to resolve uncertainties. The authors also suggested several different classification schemes that are possible depending on the choice of pairwise evolutionary distance (PED) levels (Table 4).

The studies by Bao et al. and Lauber et al. [2, 12] revealed that Lloviu virus was more closely related to ebolaviruses than to marburgviruses. Lauber et al. [12] confirmed the separate status of LLOV and suggested that the family be possibly divided into two subfamilies for the genera Ebolavirus+Cuevavirus on the one hand and Marburgvirus on the other (Table 4).

The third study was published by Peterson et al. and primarily addressed the classification of marburgviruses [14]. The results of the study confirmed the previous Study Group's decision to separate RAVV from MARV but suggested that RAVV be classified in its own species, separate from Marburg marburgvirus [14], reminiscent of one possible classification suggested by Lauber et al. [12] (Table 4, far right column).

Based on available and published data, the current Study Group members voted unanimously (17:0) to go forward with the proposal to establish a novel species "Lloviu cuevavirus" included in a new genus "Cuevavirus" for Lloviu virus. Consequently, the ICTV Executive Committee's stated concerns about the previously submitted version of this proposal were addressed in a rebuttal; the taxoprop was updated, corrected and partially rewritten; and both the taxoprop and the rebuttal were submitted to the ICTV on June 24, 2013. The proposal was accepted by the ICTV Executive Committee on August 5, 2013, and now awaits ratification.

The analysis by Lauber et al. suggested the possible need to establish filovirus subfamilies. The Study Group voted 15:2 against such a move at this point in time. Study Group members who voted against the establishment of subfamilies argued that at the moment no pressing scientific problem would be solved, that more data need to be accumulated before such a taxonomy change could be seriously debated, and that too many changes in filovirus taxonomy would be confusing to the filovirology community. Study Group members who voted in favor of a change argued that the establishment of subfamilies would visualize the closer relationship of LLOV to ebolaviruses compared to marburgviruses.

Alternative filovirus classifications suggested as possibilities by Lauber et al. and Bao et al. (Table 4) were not seen as beneficial by any Study Group member at this point in time ( 0 out of 17 votes in favor), and the current filovirus 


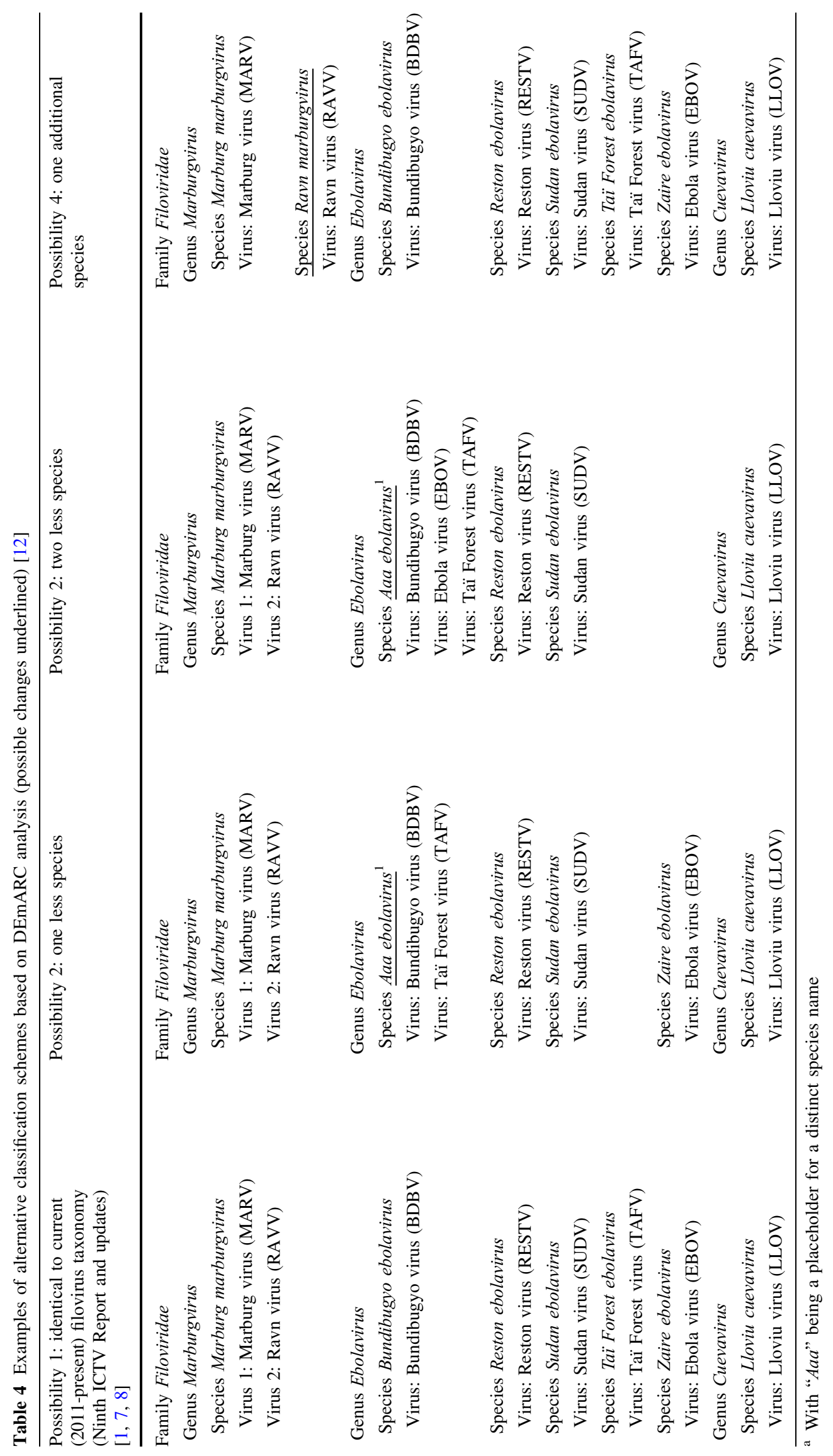


taxon demarcation criteria were seen as sufficiently correct for classification ( 0 out of 17 votes in favor of changing demarcation criteria).

Finally, the Study Group voted on the question whether a novel species should be established for Ravn virus. Thirteen Study Group members voted against such a move based on the fact that it is currently impossible to distinguish between Ravn virus and Marburg virus biologically, clinically, or serologically, and based on the finding that both viruses occupy the same ecological niche (fruit bats of the species Rousettus aegyptiacus) in the same geographic area. Four Study Group members voted for the establishment of a novel species based on the rather distinct genomic sequence of Ravn virus compared to Marburg virus.

\section{Does filovirus nomenclature need to be changed?}

Since closure of Study Group discussions in 2012, an additional concern was brought to the attention of the Chair regarding the "Ebola virus vs. Ebolavirus/ebolavirus" and the "Marburg virus vs. Marburgvirus/marburgvirus" differentiation issue. The phrases "Ebola virus" and "Ebolavirus/ ebolavirus", as well as the phrases "Marburg virus" and "Marburgvirus/marburgvirus" are pronounced identically in most oral proceedings. The pronunciation of "Ebola virus" and of "Ebolavirus/ebolavirus" is theoretically different (IPA: ع'bplə vaIrəs vs. i:,bovlə'vaIrəs), but that this difference is rarely adhered to [7].

The Study Group therefore re-visited the possibilities for nomenclature changes outlined in Table 3 and discussed alternatives. One Study Group member voted for changing the species name Zaire ebolavirus to Ebola ebolavirus (Table 3, Possibility 2). One Study Group member voted for a change of filovirus genus names and subsequently a change of all species names (Table 3, Possibility 3). One Study Group member voted to change all ebolavirus names and all their abbreviations, all ebolavirus species names, the abbreviation for Marburg virus, and the species name Marburg marburgvirus, partially in contradiction to ICVCN rules (not shown). Fourteen Study Group members voted not to change the current nomenclature because any changes at this point in time would lead to increased confusion, and because it was generally felt that the differentiation of "Ebola virus" and "ebolavirus" is not intellectually challenging enough to warrant corrective action.

\section{Other current activities of the ICTV Filoviridae Study Group}

Sixteen of the 17 Study Group members also informed and voted during discussions of the larger filovirus research community regarding the establishment of a consistent nomenclature of filovirus strains, variants, and isolates for electronic databases [9-11].

Acknowledgments We thank ICTV Executive Committee member and the ICTV Vertebrate Virus Subcommittee Chair Andrew J. Davison (University of Glasgow, UK) for ensuring that ICTV process is described accurately in this article, and Laura Bollinger (NIH/NIAID Integrated Research Facility at Fort Detrick, Frederick, MD, USA) for critically editing the manuscript.

\section{References}

1. Adams MJ, Carstens EB (2012) Ratification vote on taxonomic proposals to the International Committee on Taxonomy of Viruses (2012). Arch Virol 157:1411-1422

2. Bao Y, Chetvernin V, Tatusova T (2012) PAirwise Sequence Comparison (PASC) and its application in the classification of filoviruses. Viruses 4:1318-1327

3. Feldmann H, Geisbert TW, Jahrling PB, Klenk H-D, Netesov SV, Peters CJ, Sanchez A, Swanepoel R, Volchkov VE (2005) Family Filoviridae. In: Fauquet CM, Mayo MA, Maniloff J, Desselberger U, Ball LA (eds) Virus taxonomy-Eighth Report of the International Committee on Taxonomy of Viruses. Elsevier/Academic Press, San Diego, pp 645-653

4. Johnson KM, Lange JV, Webb PA, Murphy FA (1977) Isolation and partial characterisation of a new virus causing acute haemorrhagic fever in Zaire. Lancet 1:569-571

5. King AMQ, Adams MJ, Carstens EB, Lefkowitz EJ (2011) The Statutes of the ICTV. In: King AMQ, Adams MJ, Carstens EB, Lefkowitz EJ (eds) Virus taxonomy-Ninth Report of the International Committee on Taxonomy of Viruses. Elsevier/Academic Press, London, pp 1269-1272

6. King AMQ, Adams MJ, Carstens EB, Lefkowitz EJ (2011) The International Code of Virus Classification and Nomenclature. In: King AMQ, Adams MJ, Carstens EB, Lefkowitz EJ (eds) Virus taxonomy-Ninth Report of the International Committee on Taxonomy of Viruses. Elsevier/Academic Press, London, pp $1273-1277$

7. Kuhn JH, Becker S, Ebihara H, Geisbert TW, Johnson KM, Kawaoka Y, Lipkin WI, Negredo AI, Netesov SV, Nichol ST, Palacios G, Peters CJ, Tenorio A, Volchkov VE, Jahrling PB (2010) Proposal for a revised taxonomy of the family Filoviridae: classification, names of taxa and viruses, and virus abbreviations. Arch Virol 155:2083-2103

8. Kuhn JH, Becker S, Ebihara H, Geisbert TW, Jahrling PB, Kawaoka Y, Netesov SV, Nichol ST, Peters CJ, Volchkov VE, Ksiazek TG (2011) Family Filoviridae. In: King AMQ, Adams MJ, Carstens EB, Lefkowitz EJ (eds) Virus taxonomy-Ninth Report of the International Committee on Taxonomy of Viruses. Elsevier/Academic Press, London, pp 665-671

9. Kuhn JH, Bao Y, Bavari S, Becker S, Bradfute S, Brauburger C, Brister JR, Bukreyev AA, Cai Y, Chandran K, Davey RA, Dolnik O, Dye JM, Enterlein S, Gonzalez JP, Formenty P, Freiberg AN, Hensley LE, Hoenen T, Honko AN, Ignatyev GM, Jahrling PB, Johnson KM, Klenk HD, Kobinger G, Lackemeyer MG, Leroy EM, Lever MS, Lofts LL, Muhlberger E, Netesov SV, Olinger GG, Palacios G, Patterson JL, Paweska JT, Pitt L, Radoshitzky SR, Ryabchikova EI, Saphire EO, Shestopalov AM, Smither SJ, Sullivan NJ, Swanepoel R, Takada A, Towner JS, van der Groen G, Volchkov VE, Wahl-Jensen V, Warren TK, Warfield KL, Weidmann M, Nichol ST (2013) Virus nomenclature below the species level: a standardized nomenclature for recombinant 
strains and variants of viruses assigned to the family Filoviridae. Arch Virol

10. Kuhn JH, Bao Y, Bavari S, Becker S, Bradfute S, Brister JR, Bukreyev AA, Cai Y, Chandran K, Davey RA, Dolnik O, Dye JM, Enterlein S, Gonzalez JP, Formenty P, Freiberg AN, Hensley LE, Honko AN, Ignatyev GM, Jahrling PB, Johnson KM, Klenk HD, Kobinger G, Lackemeyer MG, Leroy EM, Lever MS, Lofts LL, Muhlberger E, Netesov SV, Olinger GG, Palacios G, Patterson JL, Paweska JT, Pitt L, Radoshitzky SR, Ryabchikova EI, Saphire EO, Shestopalov AM, Smither SJ, Sullivan NJ, Swanepoel R, Takada A, Towner JS, van der Groen G, Volchkov VE, Wahl-Jensen V, Warren TK, Warfield KL, Weidmann M, Nichol ST (2013) Virus nomenclature below the species level: a standardized nomenclature for laboratory animal-adapted strains and variants of viruses assigned to the family Filoviridae. Arch Virol 158:1425-1432

11. Kuhn JH, Bao Y, Bavari S, Becker S, Bradfute S, Brister JR, Bukreyev AA, Chandran K, Davey RA, Dolnik O, Dye JM, Enterlein S, Hensley LE, Honko AN, Jahrling PB, Johnson KM, Kobinger G, Leroy EM, Lever MS, Muhlberger E, Netesov SV, Olinger GG, Palacios G, Patterson JL, Paweska JT, Pitt L, Radoshitzky SR, Saphire EO, Smither SJ, Swanepoel R, Towner JS, van der Groen G, Volchkov VE, Wahl-Jensen V, Warren TK, Weidmann M, Nichol ST (2013) Virus nomenclature below the species level: a standardized nomenclature for natural variants of viruses assigned to the family Filoviridae. Arch Virol 158:301311
12. Lauber C, Gorbalenya AE (2012) Genetics-based classification of filoviruses calls for expanded sampling of genomic sequences. Viruses 4:1425-1437

13. Negredo A, Palacios G, Vazquez-Moron S, Gonzalez F, Dopazo H, Molero F, Juste J, Quetglas J, Savji N, de la Martinez M, Herrera JE, Pizarro M, Hutchison SK, Echevarria JE, Lipkin WI, Tenorio A (2011) Discovery of an ebolavirus-like filovirus in europe. PLoS Pathog 7:e1002304

14. Peterson AT, Holder MT (2012) Phylogenetic assessment of filoviruses: how many lineages of Marburg virus? Ecol Evol 2:1826-1833

15. Siegert R, Shu HL, Slenczka W, Peters D, Müller G (1967) On the etiology of an unknown human infection originating from monkeys. Dtsch med Wochenschr 92:2341-2343

16. Towner JS, Sealy TK, Khristova ML, Albarino CG, Conlan S, Reeder SA, Quan PL, Lipkin WI, Downing R, Tappero JW, Okware S, Lutwama J, Bakamutumaho B, Kayiwa J, Comer JA, Rollin PE, Ksiazek TG, Nichol ST (2008) Newly discovered Ebola virus associated with hemorrhagic fever outbreak in Uganda. PLoS Pathog 4:e1000212

17. Van Regenmortel MH, Burke DS, Calisher CH, Dietzgen RG, Fauquet CM, Ghabrial SA, Jahrling PB, Johnson KM, Holbrook MR, Horzinek MC, Keil GM, Kuhn JH, Mahy BW, Martelli GP, Pringle C, Rybicki EP, Skern T, Tesh RB, Wahl-Jensen V, Walker PJ, Weaver SC (2010) A proposal to change existing virus species names to non-Latinized binomials. Arch Virol 155:1909-1919 